\title{
Student nurse attrition: A half century of research
}

\author{
Brett R. Merkley * \\ Carolyn McKelvey Moore School of Nursing, University of Arkansas-Fort Smith, Fort Smith, AR, United States
}

Received: September 19, 2015

Accepted: November 9, $2015 \quad$ Online Published: November 25, 2015

DOI: $10.5430 /$ jnep.v6n3p71

URL: http://dx.doi.org/10.5430/jnep.v6n3p71

\begin{abstract}
This descriptive literature review examines 50 years of research related to student nurse attrition within nursing education programs. Retention, attrition, drop-out, stop-out, and wastage are terms used over the decades to describe student nurse progress. The objective of the literature review was to identify and accept this global issue, review the evidence, and to identify potential gaps in the literature. An extensive literature review within multiple databases rendered multidimensional interrelated factors involving: The student nurse, learning environment and nurse educator, and clinical placement; yet the issue of student attrition persists. There may be another factor to consider: Policy. What influence does policy have on student nurse retention and attrition? This study examined current research evidence related to nursing student attrition and discusses layers of policy embedded in nursing education programs. Nursing program progression policies and non-uniform grading policies can be factors of students' failure to progress.
\end{abstract}

Key Words: Student nurse, Attrition, Drop-out, Retention, Education policy

\section{INTRODUCTION}

Attrition and retention have been significant issues in undergraduate nursing education programs across the globe. ${ }^{[1-3]}$ Early discussions and study of student nurse attrition began in the 1960s. ${ }^{[4]}$ The literature reveals that nursing student attrition rates are too high, as much as $50 \%$ in some baccalaureate nursing programs. ${ }^{[5,6]}$ Student attrition is a research focus today with diverse research methodologies and findings. The extensive literature review included electronic database searches in PubMed, EBSCOhost, Ovid, CINAHL, ProQuest, and ERIC.

\section{LITERATURE REVIEW METHODS \\ 2.1 The objective}

The search strategy would include common terms associated with student nurse attrition. The goal of the literature review was to identify and accept student nurse attrition as a global issue, review the evidence, and to identify potential gaps in the literature.

\subsection{Design}

Associated database Boolean phrases and search terms included: Student nurse AND attrition; student nurse attrition; student nurse drop-out; and nurse education policy. This study would include search outcomes from 1965 to 2015. The sources would include only journal articles. The literature search initially included phrases and related terms, which were narrowed by searching phrases with no related terms, and by eliminating duplicate search results. Search results were further reduced by visual review of the article title and abstract. Additional criteria of undergraduate nursing students from both associated degree and baccalaureate programs were applied. Graduate students were excluded. At the conclusion of the review process there were 42 articles to review and apply. Table 1 illustrates the search results and the process of narrowing within the databases.

\footnotetext{
* Correspondence: Brett R. Merkley; Email: brett.merkley@uafs.edu; Address: Carolyn McKelvey Moore School of Nursing, University of Arkansas-Fort Smith, Fort Smith, AR, United States.
} 
Table 1. Search terms and reducing process

\begin{tabular}{lll}
\hline Boolean/Phrase and Search Terms & Results Including Related Terms & Results No Related Terms \\
\hline Nursing student dropout & 20,488 & 59 \\
Nursing student attrition & 20,001 & 22 \\
Student nurse AND attrition AND dropout & 63 & 4 \\
Student nurse AND (attrition or retention) & 315 & 9 \\
Nursing education policy & 10,259 & 4,220 \\
Nursing education policy AND student & 4,220 & 11 \\
\hline
\end{tabular}

\subsection{Search outcomes}

The articles included in this descriptive literature review derived several research themes, such as the student; environment of learning, the nurse educator, and clinical placement. The literature results for the search terms of nursing education policy AND student were found only in ERIC. The breath of the review revealed a gap related to policy in nursing education; and its influence on student retention and attrition. This descriptive literature review assembles the research evidence for student attrition, identifies research themes associated with student nurse attrition, and discusses common policies within nursing programs which may influence student retention and attrition.

\section{EVIDENCE AND RESULTS}

\subsection{The student nurse}

Pre-nursing background and the nursing students' academic preparation, academic performance, purpose, health, and socioeconomics are interrelated factors influencing a student's success or failure. Tinto's model (1975), frequently cited in the literature, described multiple variables and the social relationships between the student and the institution. ${ }^{[7]}$ Jeffrey's Nursing Universal Retention and Success Model ${ }^{[2]}$ identified student profile characteristics, affective factors, and the student's background environment, which included family finances, emotional support, and responsibilities. Merrifield ${ }^{[8]}$ found that prior health care assistant experience did not lead to success in nursing coursework. Despite this evidence, this type of nursing care requirement is often desired of student applicants, in an effort for nursing programs to manage student retention and attrition.

Students enter nursing education with diverse social, economic, and education backgrounds. Retaining these students has been a challenge for half a century. Urwin, Stanley, Jones, Gallagher, Wainwright \& Perkins ${ }^{[9]}$ concluded, the likelihood of a student successfully completing or dropping out is related to multiple factors and not a single student attribute. Academically strong students may endure academic and financial problems while, for the weaker student, these problems may be the last straw. ${ }^{[10]}$ Attributes sup- porting student completion include inner strength and high self-determination, and student factors included pre-course preparation, outside support of family and friends, and tutor support. ${ }^{[11]}$ The 2003 Deary, Watson, and Hogston study of student burnout and attrition, found certain personality traits and coping strata remained stable for first to second year nursing students. Student attributes which endured were: openness and agreeableness, and the coping styles which endured were identified as emotion-oriented, task-oriented, and distraction coping. ${ }^{[12]}$

The study of student nurse success and Maslow's hierarchy of needs by Freitas and Leonard ${ }^{[13]}$ included 135 student subjects with data analysis calculated by ANOVA and correlation statistics. They conclude that a significant number of nursing students were not confident about meeting physiologic needs. In the academic support for these students, they need to be aware of, and be referred to funding sources to help improve their academic success and retention. ${ }^{[13]} \mathrm{Al}-$ though anecdotal, the inclusion of a student's perspective of student drop-out rates will be considered. A nursing student writes:

We have 4 (four) exams, no quizzes, no extra credit. None of the prereq (pre requisite) classes prepared us for NCLEX style questions, and I know, if given more of a chance, some of those that failed out would have gotten it. $^{[14]}$

Abundant learning resources are available for nursing students to develop test-taking strategies. Parsh, Sanders \& Lilyquist ${ }^{[15]}$ asked why teach an NCLEX prep class? They proved a guide for elements of the preparation course. Early introduction to test-taking strategies should be considered. The literature and seminars cited often refer to end of program studies or senior-year nursing students. Herrman ${ }^{[16]}$ developed a senior level seminar course for nursing students to learn specific strategies for the standardized nurse licensure exam. This seminar blueprint is made available to any baccalaureate nursing program.

In March and April of 2008, the Massachusetts Nursing Association held meetings titled, "The Real Nursing World-

ISSN 1925-4040 E-ISSN 1925-4059 
Transition from Student to RN" which provided senior nursing students with information and strategies to transition from student to professional, and included a seminar on how to pass the nursing board exam. ${ }^{[17]}$ Abundant student testtaking resources are available within nursing organizations and publisher resources to support the nursing student from start to graduation. Study modules or seminars introduced early in a program may improve student test-taking skills and student success throughout the coursework.

\subsection{Learning environment and instructor}

The literature identified the environment of learning as a research theme relevant to student nurse retention and attrition. The learning environment today occurs with and without walls, at school and at home; and provides myriad of technologies for the student learner and the instructor. The vision for the International Society for Technology in Education states that multimedia can make curriculum come alive as the student and the teacher explore deeper content. It also helps the student master critical thinking skills. ${ }^{[18]}$ Developing nursing courses designed to enhance a student's critical thinking abilities can improve student progress. ${ }^{[5]}$ Herrera and Blair ${ }^{[19]}$ performed a study of 325 nursing students and found that a student's grade in human pathophysiology is predictive of a nursing student's success in the adult medical surgical nursing course. Andrew, Salamonson, Weaver, Smith, O'Reilly \& Taylor ${ }^{[20]}$ discussed classroom instruction and found none of the departed seventeen students' surveyed mentioned dissatisfaction with the quality of teaching as a reason for leaving. However, uncivil nursing faculty behaviors in the classroom can create barriers to the teachinglearning environment resulting in decreased student program satisfaction. $^{[21]}$

In an effort to improve retention rates, Gillen ${ }^{[22]}$ notes, the University of Worchester in the United Kingdom introduced new nursing students with a short film with narrations from current nursing students describing the challenges and rewards of specific nursing courses. Student retention rates improved almost twenty-five percent in the first-to-second year student cohort following the pre-emptive efforts. ${ }^{[22]}$ Gillen $^{[23]}$ notes a nurse led study at Staffordshire University found that providing students a faculty mentor to meet with regularly throughout the semester improved student competencies. Additionally, Gillen ${ }^{[23]}$ noted tutors provide nursing students with quality contact, which was reported to reduce attrition rates significantly. The classroom experience and appropriate learning resources are important factors in student nurse success. Spurlock ${ }^{[24]}$ stated accountability for student success is a partnership between student and teacher: Faculty have a responsibility to offer high quality instruction and

Published by Sciedu Press clinical experiences which prepare students for professional nursing practice.

\subsection{Clinical placement}

Clinical placement is another theme derived from the literature review. Students often speak about clinical placements; and if they are not provided good placement early in the program, they often become disillusioned. ${ }^{[25]}$ Eick, Williamson $\&$ Heath $^{[26]}$ performed a systematic review of placementrelated attrition in nurse education. Eighteen articles met the study criteria. They found placement experiences and related factors are part of the process in a student's decision to continue or to drop-out, and a students' clinical placement was a factor, and one of the reasons why a student or peer considered leaving. Eick ${ }^{[26]}$ also identify specific student placement factors, which include unpleasant experiences, acceptance in the workplace, perceived lack of support, perceptions of nursing as a profession, and perceptions of practice assessment.

As a clinical instructor, the professional demeanor modeled between student and workplace staff can temper the environment of care, and the most effective time to start is at the beginning of the clinical day. The instructor should be available throughout the day to offer continuous student support as needed. The ratio of 1:10 clinical faculty to student group is set by most state boards of nursing. Some believe this ratio is too high, recommending a 1:8 ratio of clinical faculty to nursing student group. ${ }^{[27]}$ Pryjmachuk et al. ${ }^{[3]}$ stated their research overlooked the impact of placement on attrition: Concluding more consideration is needed to address the influence of placement providers in relation to student support and retention. The Pryjmachuk study also noted multifactor influences for attrition and recommended a multi-layered strategy to support student success.

\subsection{Policy}

Policies considered include legislative, organizational, academic, and nursing program. Legislative decisions impact student and faculty in nursing education programs. Current Federal policy considers consolidating federal funding for nursing education and workforce into block grants to states. This policy ${ }^{[28]}$ also supports the appropriate balance of clinical and simulation education in developing clinical nursing skills as reported by the Robert Wood Johnson Foundation (RWJF). In 2010, the Institute of Medicine (IOM) report in The Future of Nursing: Leading Change, Advancing Health, issued recommendations and goal for 2020 to achieve an $80 \%$ baccalaureate-prepared nursing workforce. Meeting this goal for 2020 means increasing from a $40 \%$ baccalaureate-prepared nursing workforce to $80 \%$ in ten 
years. This recommendation has placed pressure on states and academic institutions to increase baccalaureate-prepared nursing graduates. The IOM (2010) recommendation may have also influenced the discontinuation of many associate degree nursing programs at colleges and universities within the United States. Labor policies also play and important role in determining the size of the long-term care workforce, ${ }^{[29]}$ which included nursing professionals.

State policies and funding are considered in legislative efforts nation-wide. The $\mathrm{RWJF}^{[28]}$ recommended that states improve funds to make faculty salaries and benefits attractive and spurring innovative partnership and to allocate nursing education funds predicated on graduation rates and other performance outcomes. State boards of nursing are addressing nursing competencies and comprehensive frameworks for nursing education. State-wide and regionally shared competency curriculum are being championed to enhance nursing degree progress and to unify nursing education. ${ }^{[30]}$

Nursing programs might consider unifying the grading policies throughout nursing programs and institutions. Achieving an " $\mathrm{A}$ " grade for a certain percent score in one nursing program may be a "B" grade in another nursing program. Non-cohesive and unified agreement upon grading policies in nursing education may result in the apple not being an apple; especially as undergraduates consider graduate education. Grading policy inconsistencies between programs and within institutions can be a factor for student attrition. This descriptive review study realizes that a survey of undergraduate nursing program grading policies around the globe would add important evidence to the issue of student nurse attrition. However, the limited funding and scope of this study prevents exploration at this time.

Additional policies in nursing programs often include academic progression requirements. Massey ${ }^{[31]}$ found nursing students who fail a course, fall out of program sequence. Reinstatement policies and sequencing rules can be a factor in student progress and success. Students will attempt to reenter or retake the course with the understanding they would have a second chance, then be informed that there is no space available.

Program use of high stakes testing, adapted from other public schools and disciplines are now included in many nursing

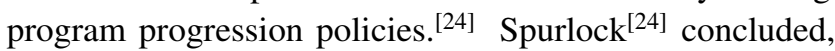
those which include high-stake exams within progression policies should consider the scholarly evidence and recommendations of education organizations which discourage or prohibit single high-stakes testing. Nursing faculty should invite excellence in the teacher-learner environment throughout program curriculum to improve student progress and success on the NCLEX-RN. A common outcome measure for student and program success might be licensure exam pass rates.

\section{Conclusion}

The student nurse is a complex being with multiple variables and characteristics which present strategic challenges in managing student nurse attrition and improving retention. Student attrition, as in the past, will continue to be a research target. This descriptive literature review collated the research evidence which was organized into factor themes such as; the student nurse, learning environment and nurse educator, clinical placement, and policies. The Tinto and Jeffrey models provide visual illustrations of the complex variable related to student nurse attrition. However, these two models do not address the impacts of policies and nursing student retention. Nursing program should explore the established research evidence to shape their a platforms and build a systematic processes to improve student nurse retention. This process should include the application of the research evidence and promote appropriate change for strategic program and policy development to improve student nurse retention and progress.

Retention and attrition are significant performance measures for program and institutional accreditation and may also be tied to state funding allocations. Andrew et al. ${ }^{[20]}$ declared, "Every nursing student who leaves before completing their BN course is not just a loss to the university, but also a potential loss to the nursing workforce and community". Policy is a process of change. Review, revise, and include the applicable policies at the legislative, institutional, and program levels to improve student nurse progress and retention. The limits of this study prevent the beneficial survey of undergraduate nursing program grading policies around the globe which would add important evidence to the issue of student nurse attrition. Study modules or seminars introduced early in a program may improve student test-taking skills and student success throughout the coursework. Progression and grading policies can contribute to student nurse attrition. We can learn from the literature and apply research findings to support nursing student success and progress to become well prepared nursing professionals.

\section{ACKNOWLEDGEMENTS}

Dr. Patsy Cornelius for her willingness to assist as proof reader and edit recommendations for the text. 


\section{REFERENCES}

[1] Jinks AM, Richardson K, Jones C, et al. Issues concerning recruitment, retention and attrition of student nurses in the 1950/60s: A comparative study. Nurse Education in Practice. 2014; 14(6): 641647. PMid:25107598 http://dx.doi.org/10.1016/j.nepr. 20 14.07 .002

[2] Jeffries M. Jeffrey's nursing universal retention and success model: Overview and action ideas for optimizing outcomes A-Z. Nurse Education Today. 2015; 35(3): 425-431. PMid:25434347 http: //dx.doi.org/10.1016/j.nedt.2014.11.004

[3] Pryjmachuk S, Easton K, Littlewood A. Nurse education: Factors associated with attrition. Journal of Advanced Nursing. 2008; 65(1): 149-160. PMid:19032508 http://dx.doi.org/10.1111/j.136 5-2648.2008.04852.x

[4] Brunclik H, Thurston J. Nursing student attrition. Nursing Outlook. 1965; 13(11): 57-59. PMid:5173929

[5] Abele C, Penprase B, Ternes R. A closer look at academic probation and attrition: What courses are predictive of nursing student success? Nurse Education Today. 2011; 33(3): 258-261. PMid:22177474 http://dx.doi.org/10.1016/j.nedt.2011.11.017

[6] Harris RC, Rosenberg L, O'Rourke ME. Addressing the challenges of nursing student attrition. Journal of Nursing Education. 2014; 53(1): 31-7. PMid:24328250

[7] Tinto V. Dropout from higher education: A theoretical synthesis of recent research. Review of Educational Research. 1975; 45: 89-125. http://dx.doi.org/10.3102/00346543045001089

[8] Merrifield N. Care experience fails to improve student grades or attrition rates. Nursing Times. 2015; 111: 5. Available from: http://0-search.proquest.com.uafs.iii.com/docv iew/1648383785? accountid=14481

[9] Urwin S, Stanley R, Jones M, et al. Understanding student nurse attrition: Learning from the literature. Nurse Education Today. 2010; 30(2): 202-207. PMid:19910083 http://dx.doi.org/10.1016 /j.nedt.2009.07.014

[10] Mosely L, Mead D. Predicting who will drop out of nursing courses: A machine learning exercise. Nurse Education Today. 2008; 28: 469475. PMid:17920163 http://dx.doi.org/10.1016/j.nedt. 20 07.07 .012

[11] Fowler J, Norrie P. Development of an attrition risk prediction tool. British Journal of Nursing. 2009; 18(19): 11941200. PMid:19966747 http://dx.doi.org/10.12968/bjon. 2 009.18 .19 .44831

[12] Deary IJ, Watson R, Hogston R. A longitudinal cohort study of burnout and attrition in nursing students. Journal of Advanced Nursing. 2003; 43(1): 71-81. PMid:12801398 http://dx .doi .org/1 $0.1046 / j .1365-2648.2003 .02674 . x$

[13] Freitas FA, Leonard L. Maslow's hierarchy of needs and student academic success. Teaching and Learning in Nursing. 2011; 6: 9-13. http://dx.doi.org/10.1016/j.teln.2010.07.004

[14] Ceiling C. Curious about drop-out rate in nursing school [Web log comment]. 2010. Available from: http://allnurses.com/gene ral-nursing-student/curious-about-drop-451780.html

[15] Parsh B, Sanders S, Lilyquist K. Why teach an NCLEX prep class? Nursing. 2015; 45(2): 55-56. PMid:25585224 http://dx.doi.o rg/10.1097/01. NURSE.0000459790.70430.a3
[16] Herrman JW, Johnson AN. From beta-blockers to boot camp: Preparing students for the NCLEX-RN. Nursing Education Perspectives. 2009; 30(6): 384-388. PMid:19999942

[17] More than 550 senior nursing students get tips on NCLEX preparation at MNA's transition programs. Massachusetts Nurse Advocate. 2008; 79(5): 17.

[18] Vockley M. Maximizing the impact: The pivotal role of technology in a 21 st century education system. 2007. Available from: http://files.eric.ed.gov/fulltext/ED519463.pdf

[19] Herrera C, Blair J. Predicting success in nursing programs. Research in Higher Education Journal. 2015. Available from: http: //files.eric.ed.gov/fulltext/EJ1062101.pdf

[20] Andrew S, Salamonson Y, Weaver R, et al. Hate the course or hate to go: Semester differences in first year nursing attrition. Nurse Education Today. 2008; 28(7): 865-872. PMid:18289742 http://dx.doi.org/10.1016/j.nedt.2007.12.007

[21] Luparell S. Faculty encounters with uncivil nursing students: An overview. Journal of Professional Nursing. 2004; 20(1): 59-67. http://dx.doi.org/10.1016/j.profnurs. 2003.12.007

[22] Gillen S. Success for university's efforts to lower drop-out rates. Nursing Standard. 2010; 25(2): 9, 22.

[23] Gillen S. Is enough being done to reduce undergraduate attrition rates? Nursing Standard. 2012; 27(8): 12-13. http://dx.doi .org /10.7748/ns2012.10.27.8.12.p9716

[24] Spurlock DJ. Do no harm: Progression policies and high-stakes testing in nursing education. Journal of Nursing Education. 2006; 45(8): 297-302. PMid:16915986

[25] Parish C. A war of attrition. Nursing Standard. 2004; 19(11): 14 Available from: http://0-search.proquest.com.uafs.iii. com/docview/219830770?accountid=14481

[26] Eick S, Williamson G, Health V. A systematic review of placementrelated attrition in nursing education. International Journal of Nursing Studies. 2012; 49: 1299-1309. PMid:22269138 http://dx.doi.o rg/10.1016/j.ijnurstu.2011.12.004

[27] Patton C, Lewallen LP. Legal issues in clinical nursing education. Nurse Educator. 2015; 40(3): 124-128. PMid:25501655 http: //dx.doi.org/10.1097/NNE.0000000000000122

[28] Robert Wood Johnson Foundation. Expanding America's capacity to educate nurses: Diverse, state-level partnerships are creating promising models and results. Charting Nursing's Future. 2010; 13: 1-4. Available from: http: //www.rwjf.org/en/library/research/2010/05/cnf-exp anding-americas-capacity-to-educate-nurses.html

[29] Stone R, Wiener J. Who will care for us? Addressing the long-term care workforce crisis. U.S. Department of Health and Human Services, the Urban Institute. 2001. Available from: http://aspe.hhs.gov/basic-report/who-will-car e-us-addressing-long-term-care-workforce-crisis

[30] Robert Wood Johnson Foundation. The case for academic progression. Charting Nursing's Future. 2013; 21: 1-7. Available from: http://www.rwjf.org/en/library/research/2013/ 09/cnf-the-case-for-academic-progression.html

[31] Massey J. Nursing student squeezed out of program. Terrace Standard. 2014. Available from: http://0search.proquest.com.u afs. iii. com/docview/1546189053?accountid=14481 